\title{
Upaya meningkatkan kemampuan motorik halus melalui kegiatan menjahit bervariasi dengan berbagai media di PAUD Alquran Az-Zahra Banyurip Alit
}

\author{
M. Rosikhul Ilmi \\ Universitas PGRI Semarang
}

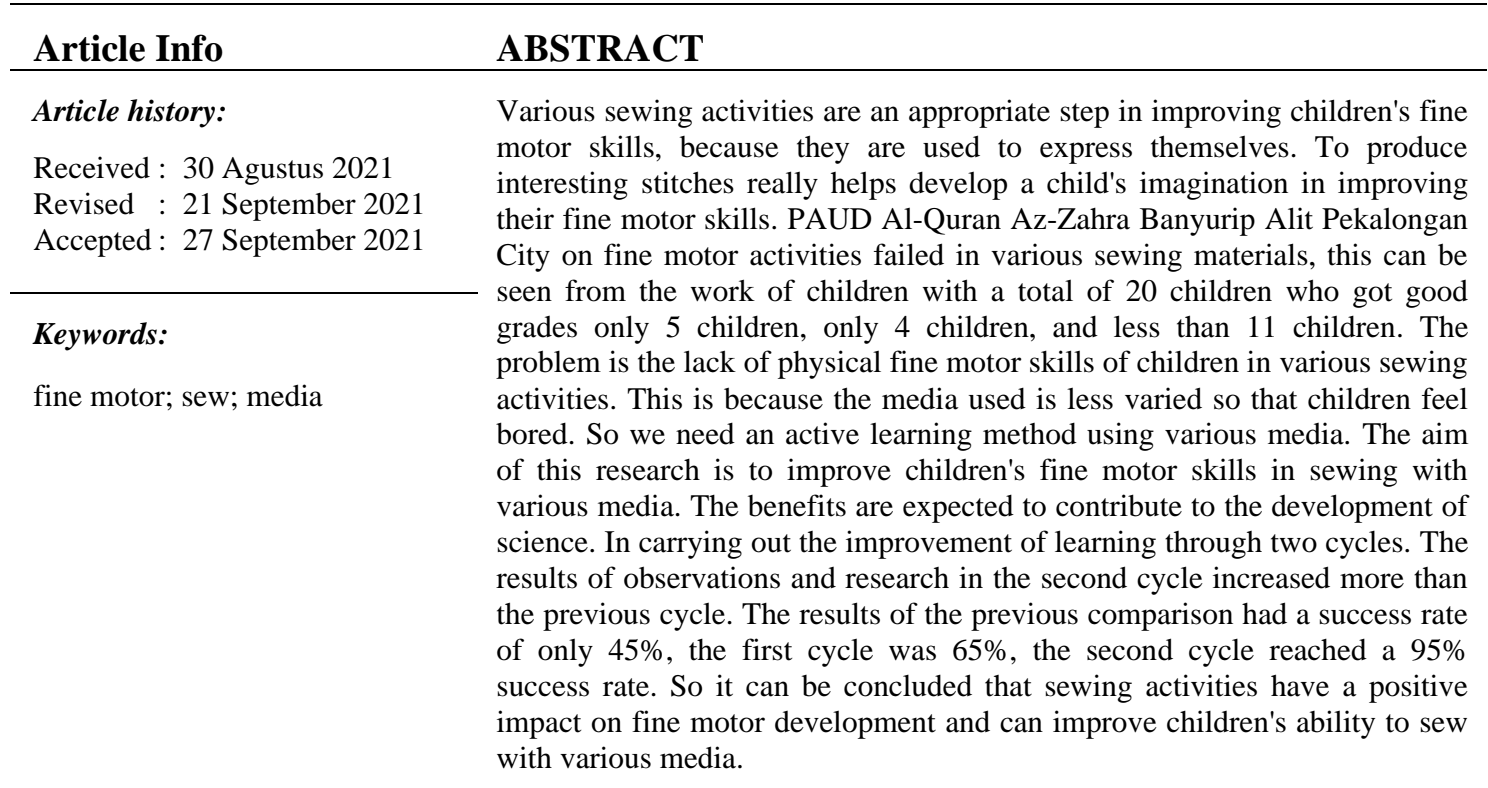

(*) Corresponding Author:

pqazzahrabanyurip@gmail.com

How to Cite: Ilmi, M. R. (2021). Upaya meningkatkan kemampuan motorik halus melalui kegiatan menjahit bervariasi dengan berbagai media di PAUD Alquran Az-Zahra Banyurip Alit. Action Research Journal, 1(1): 157159.

\section{PENDAHULUAN}

PAUD Alquran Az-Zahra Banyurip Alit merupakan lembaga yang memberikan layanan pendidikan kepada anak usia dini. Para pendidik di lembaga ini harus dapat memberikan layanan secara professional dalam rangka peletakan salah satu dasar ke arah pengetahuan dan ketrampilan agar mereka mempersiapkan diri dalam memasuki pendidikan dasar. Setiap anak didik memiliki karakter berbeda-beda sehingga guru harus dapat memahami masing-masing kesulitan yang dihadapi anak didiknya sehingga proses belajar mengajar lebih baik, namun kenyataannya masih ada ketidak sesuaian antara harapan guru dengan keberhasilan siswa, maka guru harus meningkatkan strategi pembelajaran yang didukung dengan media yang tepat pula, agar dapat meningkatkan minat anak didalam mengikuti pembelajaran. Pembelajaran yang belum sesuai dengan harapan penulis adalah pembelajaran dalam bidang pengembangan fisik motorik halus. Dalam kegiatan menjahit bervariasi dengan menggunakan berbagai media. Masih perlu diperbaiki dengan cara memberikan motivasi kepada anak, penggunaan media yang tepat dengan menggunakan media bermain.

Menurut Heinich, Molenda dan Russel (1993), media merupakan saluran komunikasi, media berasal dari bahasa Latin dan merupakan bentuk jamak dari kata medium yang secara harfiah berarti perantara, yaitu perantara sumber pesan (a source) dengan penerima pesan ( $a$ receiver). Mereka mencontohkan media ini dengan film, televisi, diagram, bahan tercetak, 
komputer dan instruktur. Manfaat media diantaranya: mengongkretkan konsep-konsep yang abstrak, menghadirkan objek-objek yang terlalu berbahaya atau sukar didapat ke dalam lingkungan belajar, menampilkan objek yang terlalu besar, memperhatikan gerakan yang terlalu cepat, memungkinkan anak berinteraksi secara langsung dengan lingkunganya, membangkitkan motivasi belajar anak, serta menyajikan dan informasi belajar secara serempak bagi seluruh anak. Media yang digunakan untuk menjahit adalah kertas, kardus, kain flanel, tripleks, alat yang digunakan seperti benang jagun, benang wol, tali rafia, tali sepatu, jarum, gunting.

Setelah melihat gejala-gejala di atas, maka terlihat kurangnya minat anak dalam bidang pengembangan fisik motorik halus dalam kegiatan menjahit bervariasi. Oleh karena itu penulis merasa perlu melakukan suatu penelitian dengan judul "Upaya Meningkatkan Kemampuan Motorik Halus Melalui Kegiatan Menjahit Bervariasi dengan Berbagai Media di Kelompok Ba' PAUD Alquran Az-Zahra Banyurip Alit Kota Pekalongan".

Harapan penulis pada akhir pembelajaran kemampuan menjahit bervariasi dengan berbagai media, agar anak PAUD Alquran Az-Zahra Banyurip Alit Kota Pekalongan dapat mengikuti kegiatan fisik motorik halus dengan tekun sehingga dapat mencapai target hasil maksimal berdasarkan hasil pengamatan pembelajaran ketrampilan menjahit bervariasi, maka dapat terungkap hasil refleksi dari masalah-masalah pembelajaran yang terjadi dalam pembelajaran.

\section{METODE}

Penelitian ini dilaksanakan di kelompok BA' di PAUD Alquran Az-Zahra Banyurip Alit Kota Pekalongan semester I tahun pelajaran 2021/2022. Penelitian merupakan Penelitian Tindakan Kelas dimana terdapat empat tahap di dalamnya untuk setiap siklus, yaitu perencanaan tindakan, penerapan tindakan, observasi, dan refleksi. Analisis data penelitian digunakan statistik deskriptif berupa persentase capaian. Jika pada siklus 1 tidak mencapai capain yang diharapkan dilaksanakan siklus 2 dan seterusnya.

\section{HASIL DAN PEMBAHASAN \\ Hasil}

\section{Perbaikan Siklus I}

Dalam kegiatan perbaikan siklus I yang dilaksanakan tanggal 17-21 Agustus 2021, untuk memperbaiki kegiatan pengembangan upaya meningkatkan kreativitas motorik halus anak dalam kegiatan menjahit pada kelompok BA' di PAUD Alquran Az-Zahra Banyurip Alit Kota Pekalongan semester I tahun pelajaran 2021/2022, yang telah didiskusikan dengan teman sejawat dan pembimbing.

2. Perbaikan Siklus II

Dalam kegiatan perbaikan siklus II yang dilaksanakan pada tanggal 24-28 Agustus 2021, untuk memperbaiki kegiatan pengembangan upaya meningkatkan kemampuan motorik halus melalui Kegiatan Menjahit Bervariasi dengan Berbagai Media di Kelompok Ba' PAUD Alquran Az-Zahra Banyurip Alit Kota Pekalongan semester I tahun pelajaran 2021/2022. Yang telah di diskusikan dengan teman sejawat dan pembimbing.

\section{Pembahasan}

\section{Pra Siklus}

Hasil kegiatan menjahit di kelompok Ba' PAUD Alquran Az-Zahra Banyurip Alit Kota Pekalongan Semester I tahun pelajaran 2021/2022 belum berhasil. Pada pra siklus hasil belajar anak terlihat masih rendah terhadap kegiatan pengembangan yang penulis lakukan, dikarenakan media yang digunakan belum dapat memotivasi semua anak. Hal ini dapat dilihat dari tingkat keberhasilan anak yaitu banyak anak yang kurang memiliki kemampuan menjahit 11 anak, yang cukup memiliki kemampuan menjahit 4 anak dan yang sudah baik dalam menjahit sejumlah 5 anak saja. Hasil kegiatan pengembangan tersebut belum memenuhi kriteria keberhasilan yaitu 
45\%. Dengan adanya kegagalan pembelajaran tersebut maka perlu di adakan perbaikan dalam siklus I dan II.

2. Siklus I

Perbaikan siklus I merupakan usaha perbaikan dari hasil pembelajaran sebelumnya. Dalam kegiatan siklus I, anak terlihat semangat terhadap kegiatan belajar. Namun ada sebagian anak yang enggan melakukan kegiatan menjahit, karena kegiatan yang kurang bervariasi. Hal ini dapat dilihat dari tingkat keberhasilan anak yaitu anak yang kurang memiliki kemampuan menjahit 7 anak, yang cukup memiliki kemampuan menjahit 6 anak dan yang sudah baik dalam menjahit sejumlah 7 anak. Hasil kegiatan pengembangan tersebut masih mencapai tingkat keberhasilan $65 \%$. Untuk itu perlu diadakan perbaikan pada siklus II guna meningkatkan keberhasilan anak dalam menjahit.

3. Siklus II

Dalam kegiatan siklus II penulis secara maksimal memberikan perhatian dan bimbingan pada anak yang kurang mampu dalam kegiatan menjahit, sehingga anak tidak mengalami kesulitan dalam mengerjakan kegiatan menjahit dan kreativitas anak lebih baik serta meningkat. Hal ini dapat dilihat dari prosentase keberhasilan 95\% atau 19 anak dari 20 anak didik yang sudah mencapai indikator perkembangan. Berdasarkan data yang diperoleh dari hasil perbaikan pembelajaran siklus I dan siklus II yang telah di laksanakan pada kegiatan pembelajaran dalam lingkup perkembangan motorik halus kegiatan ketrampilan menjahit di hasilkan data perbandingan yaitu bahwa sebelum kegiatan pengembangan (pra siklus) tingkat keberhasilan anak belum tercapai (masih 45\%). Dalam perbaikan siklus I tingkat keberhasilan anak masih $65 \%$. Hal ini perlu diadakan perbaikan kembali pada siklus II. Dengan adanya kegiatan menjahit yang bervariasi melalui berbagai media, maka kemampuan anak sudah mencapai tingkat keberhasilan yang diharapkan $(95 \%)$.

\section{PENUTUP}

Dari hasil penilaian dan pembahasan perbaikan pembelajaran yang telah di laksanakan peneliti dapat disimpulkan bahwa berbagai kegiatan menjahit bervariasi yang dilaksanakan di kelompok Ba' PAUD Alquran Az-Zahra Banyurip Alit Kota Pekalongan semester I tahun pelajaran 2021/2022 telah dapat meningkatkan kemampuan anak dalam menjahit jelujur dan silang secara kualitatif. Peningkatan tersebut terlihat dari hasil pengamatan pada akhir perbaikan kegiatan pengembangan, meliputi meniru menjahit jelujur berbagai bentuk dan meniru menjahit silang berbagai bentuk. Secara kuantitatif, berdasarkan dari grafik hasil pencapaian akhir siklus II telah terjadi peningkatan dalam kemampuan menjahit jelujur dan silang pada anak sebesar $95 \%$.

\section{DAFTAR PUSTAKA}

Gunarti, W. L.S. \& Aziza, M. (2012). Metode Pengembangan perilaku dan Kemampuan Dasar Anak Usia Dini. Jakarta: Universitas Terbuka.

Dinas Pendidikan Provinsi Jawa Tengah. (2012). Model Pembelajaran PAUD. Semarang: Dinas Pendidikan Jawa Tengah.

Sujiono, B., dkk. (2010). Metode Pengembangan Fisik. Jakarta: Universitas Terbuka.

Tim PKP PG-PAUD. 2013. Panduan Pemantapan Kemampuan Profesional. Jakarta: Universitas Terbuka.

Wardani, I. \& Kuswaya, W. (2013). Penelitian Tindakan Kelas. Jakarta: Universitas Terbuka.

Winaputra, U. S, dkk. (2011). Teori Belajar dan Pembelajaran. Jakarta: Universitas Terbuka.

Zaman, B., Hernawan, A. H., \& Eliyawati, C. (2010). Media dan Sumber Belajar TK. Jakarta: Universitas Terbuka. 